\title{
Cellular and Molecular Events Underlying the Dysregulated Response of the Aged Brain to Stroke: A Mini-Review
}

\author{
Eugen Bogdan Petcu ${ }^{a, c}$ Veronica Sfredel ${ }^{e}$ Dieter Platt ${ }^{b}$ James G. Herndon ${ }^{d}$ \\ Christof Kessler ${ }^{\text {a }}$ Aurel Popa-Wagner ${ }^{\text {a }}$ \\ ${ }^{a}$ Department of Neurology, University of Greifswald, Greifswald, and ${ }^{b}$ Prof.-Dr.-D.-Platt-Stiftung für \\ Alternsforschung, Nürnberg, Germany; ${ }^{C}$ Griffith University School of Medicine, Southport, Australia; \\ dYerkes National Primate Research Center, Neuroscience Division, Emory University, Atlanta, Ga., USA; \\ eUniversity of Medicine and Pharmacy, Craiova, Romania
}

\section{Key Words}

Stroke-related mental disabilities $\cdot$ Stroke-related physical disabilities $\cdot$ Cytological response

\begin{abstract}
Background: Age-related brain injuries, including stroke, are a major cause of physical and mental disabilities. Objective: Therefore, studying the basic mechanism underlying functional recovery after brain stroke in aged subjects is of considerable clinical interest. Methods: This review summarizes the effects of age on recovery after stroke in an animal model, with emphasis on the underlying cellular mechanisms. Results: Data from our laboratory and elsewhere indicate that, behaviorally, aged rats were more severely impaired by stroke than young rats, and they also showed diminished functional recovery. Infarct volume did not differ significantly between young and aged animals, but critical differences were apparent in the cytological response to stroke, most notably an age-related acceleration in the development of the glial scar. Early infarct in older rats is associated with premature accumulation of BrdU-positive microglia and astrocytes, persistence of activated oligodendrocytes, a high incidence of neuronal degeneration and accelerated apoptosis. In aged rats, neuroepithelial-positive
\end{abstract}

cells were rapidly incorporated into the glial scar, but these neuroepithelial-like cells did not make a significant contribution to neurogenesis in the infarcted cortex in young or aged animals. The response of plasticity-associated proteins like MAP1B, was delayed in aged rats. Tissue recovery was further delayed by an age-related increase in the amount of the neurotoxic $C$-terminal fragment of the $\beta$-amyloid precursor protein $(A-\beta)$ at 2 weeks poststroke. Conclusion: The available evidence indicates that the aged brain has the capability to mount a cytoproliferative response to injury, but the timing of the cellular and genetic response to cerebral insult is dysregulated in aged animals, thereby further compromising functional recovery. Elucidating the molecular basis for this phenomenon in the aging brain could yield novel approaches to neurorestoration in the elderly.

Copyright $\odot 2007$ S. Karger AG, Basel

\section{Introduction}

Age-related brain injuries, including stroke, are a major cause of physical and mental disabilities. Therefore, studying the basic mechanism underlying functional recovery after brain stroke in aged subjected is of considerable clinical interest.

\section{KARGER}

Fax +41613061234

E-Mail karger@karger.ch

www.karger.com
(C) 2007 S. Karger AG, Basel

0304-324X/08/0541-0006\$24.50/0

Accessible online at:

www.karger.com/ger
Aurel Popa-Wagner, PhD

Department of Neurology, University of Greifswald

Ellernholzstrasse 1-2

DE-17487 Greifswald (Germany)

Tel. +49383486 6853, Fax +49383486 6876, E-Mail wagnerap@uni-greifswald.de 


\section{Stroke Models Using Aged Animals Are Clinically More Relevant than Stroke Models in Young Animals}

Aging is associated with declines in locomotor, sensory and cognitive performance in humans [1-4]. Many of these changes are due to an age-related functional decline of the brain.

Studies of stroke in experimental animals have demonstrated the neuroprotective efficacy of a variety of interventions, but most of the strategies that have been clinically tested failed to show benefit in aged humans. One possible explanation for this discrepancy between experimental and clinical studies may be the role that age plays in the recovery of the brain from insult. Indeed, age-dependent increase in the conversion of ischemic tissue into infarction suggests that age is a biological marker for the variability in tissue outcome in acute human stroke [5].

Although it is well known that aging is a risk factor for stroke [6-9], the majority of experimental studies of stroke have been performed on young animals, and therefore may not fully replicate the effects of ischemia on neural tissue in aged subjects [10-13]. In this light, the aged post-acute animal model is clinically most relevant to stroke rehabilitation and cellular studies, a recommendation made by the STAIR committee [14] and more recently by the Stroke Progress Review Group [15].

\section{Stroke Models for Aged Rats}

Over the past 10 years, several suitable models for stroke in aged rats have been established. All are based on the permanent $[12,16,17]$ or transient occlusion of the middle cerebral artery (MCAO). Transient ischemia was accomplished for 30-120 min by means of a thrombus [18], by intraluminal filament occlusion $[15,19,20]$ or by means of a hook attached to a micromanipulator [11]. Long-term hypoxia-ischemia could also be induced by unilateral common carotid artery occlusion [21].

\section{Aged Rats Have Higher Mortality Rates but Not}

Necessarily Larger Infarcts

Generally, the mortality rate in aged rats is higher than that of young rats. The age difference in mortality is greatest if occlusion is produced by means of an embolus (47 vs. 9\%) [18]. In comparison, the intraluminal filament method and photothrombosis produce lower (20-24\%) poststroke mortality rates in aged rats $[11,15,20]$.
In humans, there is no difference in infarct size with age $[21,22]$. Some studies in rats found that cerebral infarct in aged rats was the same size as in young $[11,16-18$, $23]$, while others found that the older rats had larger infarct areas $[19,20]$.

\section{Aged Animals Recover More Slowly and Less Completely than Young Animals}

Aging is associated with a declines in locomotor, sensory and cognitive performance in humans [1] and animals [2-4]. These declines are due in large part to an agerelated functional decline of the brain.

Aged persons do not recover from stroke as well as younger persons do [24]. Rehabilitation aims at improving the physical and cognitive impairments and disabilities of patients with stroke. Therefore, studies on behavioral recuperation after stroke in aged animals are necessary and welcome. Various experimental settings have been use to assess the recovery of sensorimotor functions, spontaneous activity and memory after stroke in aged rats $[13,15,16,23]$. Overall, the results indicate that aged rats have the capacity to recover behaviorally after cortical infarcts, albeit to a lesser extent than the young counterparts [12, 13, 15, 20,23]. It should be kept in mind, however, that before stroke aged rats are already impaired compared to young animals and show significantly decreased performance in a variety of tests, such as spontaneous locomotor activity [23] and the Morris water maze [25].

As shown schematically in figure 1 (based upon work in our laboratory), all rats had diminished performance on the first day following MCAO, some of which was attributable to the surgery itself. Although recovery did occur in aged rats, its onset was delayed by up to 3 or 4 days depending on the difficulty of the testing [16, 24, 26, 27]. Similar findings have been reported recently for poststroke recovery of mice prone to accelerated senescence [28].

The extent of recovery was also dependent on the complexity and difficulty of the test. For example, aged rats had difficulties in mastering complex tasks such as our neurological status test (which measures a complexity of motor, sensory, reflex and balance outcomes), the rotarod or the adhesive removal test (which are measures of somatosensory dysfunction) and the Morris water maze $[18,23,25]$. However, the recovery of aged rats on simpler tasks, such as the foot-fault test and the corner test is equivalent to that of young rats. Another factor influenc- 
Fig. 1. General time course of functional recovery after stroke in young and aged rats, along with the duration and intensity of underlying major cellular and molecular events such as neuronal death, phagocytosis, scar formation, neurotoxic factors and regeneration-promoting factors.
Fig. 2. Infarct development is accelerated in aged animals. NeuN immunohistochemistry showed a mild episode of cerebral ischemia caused moderate neuronal degeneration on post-ischemia day 3 (A) compared to the high degree of degeneration seen in aged animals (B). On day 3 , the infarcted area comprised about $7 \%$ of the cortical volume in young animals and $28 \%$ in aged rats $\left({ }^{*} \mathrm{p}<0.02\right)$. By day 7 , the volumes of cortical infarcts were nearly equal in both age groups $(\mathbf{C}, \mathbf{D}) . \mathrm{IC}=$ Infarct core; $\mathrm{IA}=$ infarcted area (i.e. the ischemic region in a mild or incipient stage of degeneration); $\mathrm{PI}=$ periinfarct. $\mathbf{A}, \mathbf{C}$ Bars $=50 \mu \mathrm{m}$.


ing the performance level of aged rats is the infarct size, such that functional impairments in the group with the largest infarcts (20\% tissue loss) were more severe than the functional impairments in the rats with $4 \%$ tissue loss [15]. Figure 1 summarizes all of these differences between young and aged rats in the timing and completeness of recovery following MCAO. The behavioral tests used to assess the recuperation after stroke are given, along with the biological significance of each test, in table 1 . 
Neurobiology of Tissue Recuperation after Stroke in Aged Animals

Poor recovery may reflect the combination of the more aggressive activation of factors leading to infarct progression (neuronal degeneration, apoptosis, phagocytosis), factors impeding tissue repair (astroglial scar, neurite inhibitory proteins) and neurotoxic factors.

At the same time, factors promoting brain plasticity and growth may be less responsive. Growth-promoting factors include growth-associated proteins GAP43 and CAP23, the growth-promoting transcription factor c-jun, the growth-promoting cell guidance molecule L1, the CDK5-inhibitor p21, microtubule-associated proteins MAP1B and MAP2, immature neurons marker doublecortin, and stem cell marker nestin [26, 29-31]. Pathogenesis of tissue damage is mainly due to inflammatory interactions involving cytokines, chemokines and leukocytes and neurotoxic factors like the C-terminal fragment of $\beta$ amyloid (A $\beta)[11,23,26,32-34]$. One of the main findings is that both timing and magnitude of these factors is dysregulated in the postischemic aged rat brain (fig. 1).

\section{Infarct Development Is Accelerated in Aged Animals}

Functional imaging studies after stroke have shown that the reorganization in peri-infarct cortex or connected cortical regions correlates closely with functional recovery [35-37]. Therefore, these regions are mostly studied at cellular and molecular levels.

There are a number of studies on the evolution of infarct volume in aged rats. We recently found that aged rats usually develop an infarct within the first few days after ischemia [27].

In contrast to young animals where the infarct area represented $7 \%$ of the ipsilateral hemisphere (fig. $2 \mathrm{~A}$ ), on day 3 , the necrotic zone of aged rats lacked NeuN immunopositivity in $28 \%$ of the ipsilateral cortical volume (fig. 2B). The infarcted area continued to expand, and by day 7 reached $35-41 \%$ of the ipsilateral cortical volume in both in young (fig. 2C) and aged rats (fig. 2D). This suggests that the timing of neuronal loss in aged rats is accelerated, but the ultimate extent of brain cell loss is not significantly different from that in young rats. It should be noted, however, that the greater number of degenerating neurons in aged rats are seen only if the infarct area is relatively large; for small infarcts there is no age difference in the number of surviving neurons in the ischemic border zones $[15,17]$.
Table 1. Behavioral tests

\begin{tabular}{|c|c|}
\hline Behavioral test & Description \\
\hline $\begin{array}{l}\text { Jeurological } \\
\text { tatus }\end{array}$ & $\begin{array}{l}\text { rat is pulled gently by the tail and the presence } \\
\text { or absence of circling is observed }\end{array}$ \\
\hline $\begin{array}{l}\text { Limb-placement } \\
\text { symmetry }\end{array}$ & $\begin{array}{l}\text { rat is held gently by the tail at the edge of a table; } \\
\text { symmetry or asymmetry of forelimb placement } \\
\text { is observed }\end{array}$ \\
\hline $\begin{array}{l}\text { dy } \\
\text { prioception }\end{array}$ & $\begin{array}{l}\text { rat is touched lightly on each side of the body } \\
\text { with a blunt probe; tests sensorimotor respon- } \\
\text { siveness }\end{array}$ \\
\hline uch & $\begin{array}{l}\text { a blunt stick is brushed against the vibrissae on } \\
\text { each side, and presence or absence of response } \\
\text { is noted; tests sensorimotor responsiveness }\end{array}$ \\
\hline $\begin{array}{l}\text { eam-walking } \\
\text { st (rotarod) }\end{array}$ & $\begin{array}{l}\text { rat is tested for its ability to maintain balance } \\
\text { while walking on a rotating rod; assesses fine } \\
\text { vestibulomotor function }\end{array}$ \\
\hline Inclined plane & $\begin{array}{l}\text { the ability of each animal to maintain its posi- } \\
\text { tion at a given angle on an inclined plane is de- } \\
\text { termined }\end{array}$ \\
\hline $\begin{array}{l}\text { Spontaneous } \\
\text { activity }\end{array}$ & $\begin{array}{l}\text { rat is placed in a large cage and the number of } \\
\text { crossings of a bisecting line is determined; as- } \\
\text { sesses interest in exploration of a novel envi- } \\
\text { ronment }\end{array}$ \\
\hline $\mathrm{T}-\mathrm{m}$ & $\begin{array}{l}\text { rat is placed in a t-maze in which one of the } \\
\text { arms of the maze is baited with a reward; tests } \\
\text { working and reference memory }\end{array}$ \\
\hline $\begin{array}{l}\text { Radial-arm } \\
\text { maze }\end{array}$ & $\begin{array}{l}\text { rat is placed in an } 8 \text {-arm radial maze, elevated } \\
60 \mathrm{~cm} \text { above the floor; tests spatial working } \\
\text { memory }\end{array}$ \\
\hline
\end{tabular}

\section{Neuronal Degeneration and Loss through Postischemic Apoptosis Are Accelerated in Aged Rats}

Fluoro-Jade B staining showed that aged rats had an unusually high number of degenerating neurons in the infarct core as early as day $3-3.5$-fold vs. young rats (fig. 3A-C). Interestingly, the number of degenerating neurons did not rise further in aged animals, even though the infarcted area continued to expand, so that by day 7 the numbers of degenerating neurons were almost the same in both age groups (fig. 3C) [23, 29].

A major cellular event that contributes to early infarct development in aged rats is augmented apoptosis [38]. Aging increases the susceptibility of the central nervous system to apoptotic events [39]. One possible mechanism 



Fig. 3. A-C The number of degenerating cells was greatly increased in aged rats shortly after stroke. Young rats: Fluoro-Jade $B$ staining showed only a few degenerating neurons in the infarct core on day $3(\mathbf{A})$. Their number then increased rapidly and reached a maximum at days $7-14$ (4-fold vs. day 3 ; p < 0.001) (C). In contrast, aged animals had a large number of degenerating neurons in the infarct core already on day 3 (B) 3.5 times higher than young rats, $\left.{ }^{*} \mathrm{p}<0.001\right)(\mathbf{C})$. The number of degenerating neurons was roughly equal in both age groups at day 7 (C).

of increased expression of pro-apoptotic proteins in aged animals is via increased NO production by constitutive NO synthase isoforms in a model of transient global ischemia [40]. The particular vulnerability of the aged brain to apoptosis is confirmed by our finding that aged rats had considerably more apoptotic cells 3 days after ischemia (fig. 3E) than young rats (fig. 3D) (2-fold increase over young rats, $\mathrm{p}<0.02$ ) (fig. $3 \mathrm{H}$ ) [27]. On day 7 , the ra-
D-H Through immunohistochemistry, apoptosis in young rats became detectable in the infarct core at day 3 (D) and was fully developed by day $7(\mathbf{F})$. Apoptosis in aged rats was fully developed by day 3 (E) and began to decline by day $7(\mathbf{G})$. Quantitatively, at day 3 the number of apoptotic cells in the infarct core of aged rats outnumbered that of young rats 2 -fold $(\mathrm{p}<0.02)$. H On day 7 , however, the ratio was reversed, i.e. apoptotic cells in young rats outnumbered those in old rats 1.7 -fold $\left({ }^{*} \mathrm{p}<0.05\right)$. IC = Infarct core; $\mathrm{PI}=$ periinfarct. $\mathbf{D}-\mathbf{G}$ Bars $=50 \mu \mathrm{m}$. tio was unexpectedly reversed such that aged rats (fig. 3G) now had a smaller number of apoptotic cells than young rats (fig. 3F) (1.7-fold difference, $\mathrm{p}<0.05$, fig. $3 \mathrm{H})$. However, if the damage to the cerebral cortex is extensive, there is no difference in infarct size or the number of cells undergoing apoptosis between aged and young adults [17]. 
Fig. 4. The number of BrdU-positive (proliferating) cells increased early in aged rats after stroke. Young rats: BrdU-positive cells increased by 5.7-fold vs. sham-operated rats $(\mathrm{p}<0.01)$ on day $3(\mathbf{A})$, reached a maximum (8-fold vs. sham-operated rats; $\mathrm{p}<0.01$ ) on day 7 , and then decreased to control levels by days 14-28 (not shown). Day 0 represents the value for sham-operated rats. Aged rats: On day 3, the infarcted hemisphere of aged rats showed significantly more BrdU-positive cells than in young rats (4-fold increase; $\mathrm{p}<0.001, \mathbf{B}$ ). The number of these cells peaked on day 7 post-stroke (4.8-fold higher than in young rats; $\mathrm{p}<0.001, \mathbf{D})$ and then abruptly declined by day 14 (not shown). Colocalization of BrdU-positive cells (red) with microglial cells (green) was maximal on day 7 in young (E inset, arrows) and aged $(\mathbf{F}$, arrows) rats. IC $=$ Infarct core; IA $=$ infarcted area (i.e. the ischemic region in a mild or incipient stage of degeneration); $\mathrm{PI}=$ periinfarct. A-D Bars $=50 \mu \mathrm{m}$.

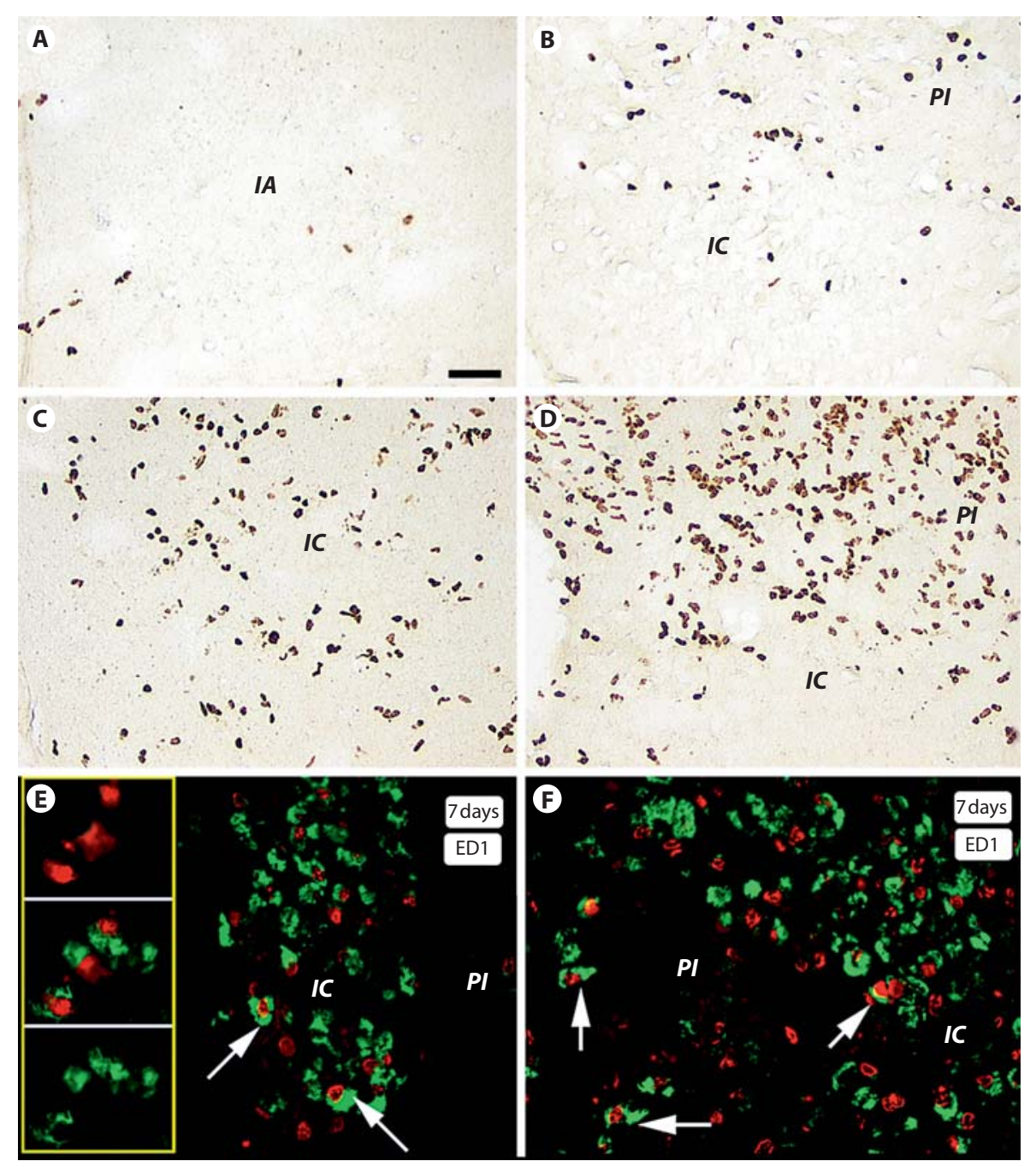

\section{Postischemic Cellular Proliferation Is Prematurely Increased in Aged Rats and Contributes to an Early Scar Buildup}

Our data not only show greater cell death in the infarct zone of aged rats on day 3 poststroke, but also that there are more newly generated cells at this time.

Pulse labeling with BrdU shortly before sacrifice revealed a dramatic increase in proliferating cells in the infarcted area of aged rats on day 3 (fig. 4B), which significantly exceeded the number in young rats at the same time point (fig. 4A). By day 7, the number of BrdUpositive cells had increased substantially in the infarcted area of young rats, too (fig. 4C). Nevertheless, the difference in the number of BrdU-positive cells remained at day 7 poststroke (fig. 4D), at which point the number of BrdU-positive cells peaked in both age groups before abruptly declining to control levels by days 14-28 (not shown).

After multiple BrdU treatments of post-stroke rats, the colocalization of monocytic (ED1) and proliferation (BrdU) markers was maximal in the infarct core on day 7 post-stroke for both young (fig. 4E) and aged (fig. 4F) rats. Although the young rats had a slightly higher cumulative rate of co-expression, i.e. about $45 \%$ of the BrdUpositive cells also were ED1 positive, compared to a $37 \%$ co-expression rate in aged rats, although this difference is not statistically significant.

The reason for the early accumulation of BrdU-positive cells in the lesioned hemisphere of aged rats remains unknown. We speculate that 2 age-associated factors could be important: (1) a decreased plasticity of the cerebral vascular wall [41] and (2) an early, precipitous inflammatory reaction to injury [23]. The increased fragil- 
Fig. 5. Comparative analysis of major cellular events in poststroke young and aged rats. A, B Inflammatory reaction. Early (day 3) appearance of phagocytic cells in the periinfarcted area of aged (B) young (A) rats. C, D Scar formation. Astrocytes become activated early after stroke in aged rats (D) and contribute to a premature formation of the glial scar. In young rats the astrocytes are much less activated (C). E, F Neurotoxic factors. Immunohistochemical staining of the neurotoxic C-terminal $\beta$-APP. The C-terminal $\beta$-APP-positive cells increased both in number and staining intensity, a process that was augmented in aged rats on day 14 (F) compared to young rats $(\mathbf{E})$. IA = Infarct area; $\mathrm{IC}=$ infarct core; PI $=$ periinfarct. $\mathbf{A}-\mathbf{F}$ Bar $=50$ $\mu \mathrm{m}$.

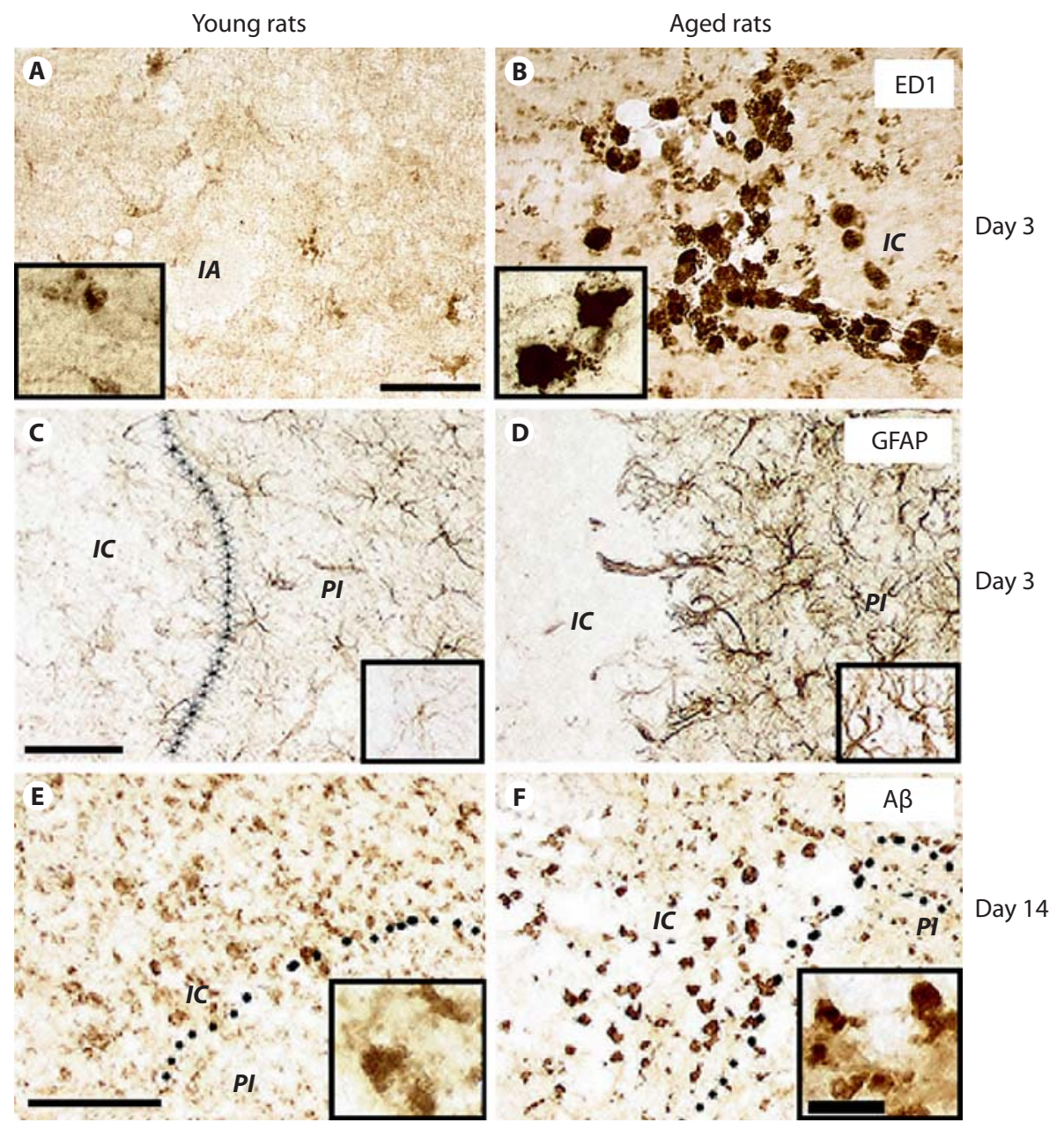

ity of aged blood vessels due to decreases in distensible components of the microvessels such as elastin [42] may lead, upon ischemic stress, to the fragmentation of cerebral capillaries that would promote the leakage of hematogenous cells into the infarct area [43, 44].

With double-labeling techniques, the proliferating cells in the aged rats brain after stroke were identified either as reactive microglia (45\%), oligodendrocyte progenitors (17\%), astrocytes (23\%), CD8+ lymphocytes $(4 \%)$, or apoptotic cells $(<1 \%)$ [27].

\section{Early, Fulminant Phagocytic Activity of Brain Macrophages in the Postischemic Aged Rat Brain}

Pathogenesis of tissue damage is mainly due to inflammatory interactions involving cytokines, chemokines and leukocytes, and to accumulation of neurotoxic factors like the C-terminal fragment of $A \beta[11,23,26$, 32-34]. Unfortunately, there are very few studies done on such factors in post-stroke aged animals.

Upon examining the phenotype, we found that many proliferating BrdU-positive cells also express markers of brain macrophages, such as ED1. The phagocytic activity of brain macrophages may contribute to the early, rapid development of the infarct in aged animals, and is part of the more general inflammatory reaction occurring after stroke $[11,23,45,46]$. Markedly increased activity of activated microglia/monocytes has also been reported in senescence-accelerated mice following intracerebral hemorrhage [28].

Activated macrophages generate free radicals, the production of which is augmented in aged subjects following cerebral ischemia $[47,48]$. A related consideration is that the vulnerability of brain tissue to traumatic injury [49], especially to DNA damage and oxidative stress, also in- 
Fig. 6. The regenerative potential of the aged brain is not exhausted. A, B Note the vigorous expression of MAP1B in the periinfarct of 3-month-old (A) and, to a lesser extent, 20-month-old rats (B) on day 14 following the stroke. C, D Similarly, MAP2 protein and mRNAs were upregulated in the periinfarcted area at almost the same levels both in young (C) and aged (D). The insets show in situ hybridization for MAP2 mRNA in the periinfarcted cortex of poststroke rats. Note that in young rats $(\mathbf{C})$ the transcript levels are higher than in aged rats (D). E, F The axonal growth marker, $\beta$-III-tubulin, had lower levels of expression in the periinfarcted area of aged rats (F) as compared to young rats (E). Morphologically, the axonal branches were thinner in aged rats. Cellular nuclei are in red. $\mathrm{IC}=$ Infarct core; PI = periinfarct. A-D Bars $=50 \mu \mathrm{m}$.
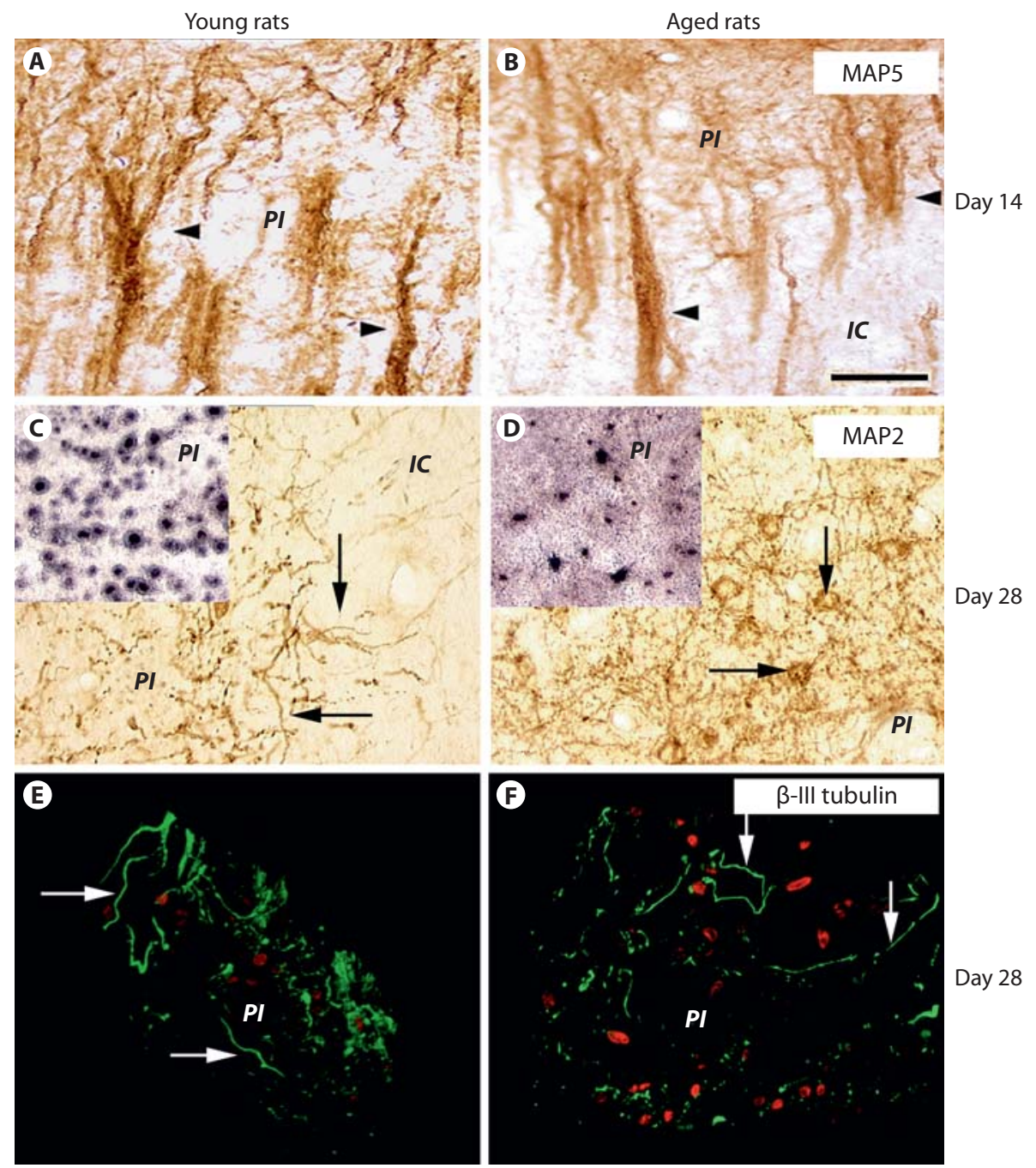

creases with age $[17,50]$. Consistent with such observations is our finding of pronounced microglia activation 3 days poststroke in aged (fig. 5B) but not young (fig. 5A) rats [23].

\section{Rapid Delimitation of the Infarct Area by Scar-Forming Nestin- and GFAP-Positive Cells}

In aged animals the infarcted area was already visible at day 3 and was circumscribed by a rim of activated astrocytes (fig. 5D). At this time point there was no accumulation of activated astrocytes in the periinfarcted area of young rats (fig. 5C).

The proliferating astrocytes lead to a premature formation of the scar in aged rats, a phenomenon that limits the recovery of function in aged animals. It should be noted that there are at least 3 cell types contributing the formation of the astroglial scar: nestin-positive cells that are the first to delineate the scar in the brains of aged rats (3 days), followed by GFAP-positive astrocytes (7 days) and finally by cells expressing the N-terminal fragment of $\beta$-APP (14 days) [23, 26, 51].

\section{Precipitous and Persistent Expression of the Neurotoxic C-Terminal Fragment of $\beta$-APP in the Infarcted Area of Aged Rats}

Cerebral ischemia promotes conditions that are favorable to the focal accumulation of neurotoxic factors such as $A \beta$, especially in the aged brain [11]. In aged rats, the 
neurotoxic C-terminal fragment of $\beta$-APP steadily accumulated over time and reached a maximum on day 14 in aged rats (fig. 5F) compared to young rats (fig. 5E).

Evidence derived from mice expressing the 100-aminoacid carboxy-terminal fragment of $\beta$-APP indicates that this fragment may promote synaptic degeneration and neuronal death [51] and impair learning [52]. Notably, the neurodegeneration is accelerated with increasing age [51]. It seems that, in general, an overexpression of $\beta$ APP695 in postmitotic neurons results in neuronal degeneration due to intracellular accumulation of this isoform [53].

\section{Regenerative Potential of the Brain Appears to Be Competent up to 20 Months of Age}

To explore the potential of older animals to initiate regenerative processes following cerebral ischemia, we studied the expression of the juvenile-specific cytoskeletal protein, microtubule-associated protein 1B (MAP1B); the adult-specific protein, microtubule-associated protein 2 (MAP2); the axonal growth marker, $\beta I I I-t u b u l i n$, in male Sprague-Dawley rats at 3 months and 20 months of age.

Focal cerebral ischemia, produced by reversible $\mathrm{MCAO}$, resulted in vigorous expression of both MAP1B penumbra of 3-month-old (fig. 6A) and, to a lesser extent, 20-month-old rats (fig. 6B) at 14 days following the stroke $[26,29]$. Similarly, MAP2 protein and mRNA were upregulated in the periinfarcted area at almost the same levels both in young (fig. 6C) and aged (fig. 6D). Somewhat lower levels of expression were noted for the axonal growth marker, $\beta$ III-tubulin, in the periinfarcted area of aged rats (fig. $6 \mathrm{~F}$ ) compared to young rats (fig. 6E). Collectively, these results suggest that the regenerative potential of the brain at the structural level is competent up to 20 months of age.

Recent studies confirm that mechanisms for self-repair in the young brain also operate in the aged brain. For example, stroke causes increased numbers of new striatal neurons despite lower basal cell proliferation in the subventricular zone in the aged brain $[54,55]$. However, despite conserved proliferative activity in the subventricular zone, the number of neurons that reach the injury site is quite modest, as was shown recently for doublecortinpositive neurons in the infarcted area of aged rats [27]. One possible explanation is that lateral ventricle-derived nestin-positive cells do not pass the corpus callosum barrier, and therefore cannot contribute to generation of neurons in the neocortex. Indeed, current evidence indicates that the great majority of newly formed cells in the adult brain are non-neuronal [56-58].

Recent studies also indicate that the molecular profile of growth-promoting genes is very different between aged and young adult groups during the sprouting response to lesions in the CNS. Aged individuals activate most growth-promoting genes at later time-points following stroke than young adults. This includes a delayed induction of GAP43, CAP23 and the growth-promoting transcription factor c-jun. The growth-promoting cell guidance molecule L1 and the CDK5 inhibitor p21 are actually downregulated during the axonal sprouting process in aged individuals compared with a robust and early upregulation of these 2 molecules in young adults [30, 31].

Few neuroprotectants are effective in aged rodents. A major goal of clinical research is to limit the infarct size and one major line of investigation has involved the hypothesis that infarct size is determined by the degree of excitotoxicity. This line of reasoning is based on the observation that excessive concentrations of glutamate can lead to neuronal death.

The failure of multiple clinical trials to demonstrate any neuroprotective efficacy of several glutamate or Nmethyl-D-aspartate receptor antagonists has led investigators to search for other potential causative mechanisms. Good candidates are antagonists to the N-methyl-D-aspartate receptor antagonist, e.g. MK-801, and the AMPA receptor antagonist, e.g. NBQX. However, both MK-801 and NBQX were found to be less-effective neuroprotectants in aged than in young rats [59]. Nevertheless, a more recent study showed that treatment of aged rats with sildenafil, a phosphodiesterase type 5 inhibitor used to enhance cGMP-mediated relaxation of pulmonary vasculature, improves functional recovery following stroke in both young and aged rats. This treatment may exert its effects by promoting brain plasticity through enhancement of angiogenesis and synaptogenesis [18].

A more general method of neuroprotection that is efficacious in young rats is ischemic preconditioning. However, the degree of protection was reduced in aged compared to young rats [60]. A likely explanation is that the brains of aged animals showed a reduced stress response that is likely to act neuroprotectively to stroke [17].

Neurosteroids have been recently shown to be effective as neuroprotective agents for ischemic stroke. Treatment with physiological concentrations of estradiol decreases ischemic injury by almost $50 \%$ compared to sham-operated controls, in both young and aging rats 
$[61,62]$. It is possible that the protective function of estradiol in this model is the suppression of apoptosis in the infarct area, resulting in enhanced neuronal survival in the penumbral region of the infarct $[61,62]$.

The use of stem cells to replace neurons lost after stroke potentially offers a novel approach to treatments aimed at improving recovery of tissue and function [63, 64]. Such a treatment might utilize the endogenous reserves of stem cells located in the subventricular zone or the subgranular zone of the hippocampus. One major concern, however, with any therapy designed to boost neurogenesis following stroke is that the capacity to produce new neurons may be diminished in the hippocampus and olfactory bulb of aged animals [65-71]. Despite this, a cause for optimism is that a variety of treatments, such as environment enrichment [72], administration of growth factors $[66,73]$ and induction of epileptic seizures [74] can increase the production of new neurons in aged animals, although at a lower level than in young animals. Even more encouraging is a recent study demonstrating the same degree of neurogenesis in the striatum of old and young animals [55]. Even though this study reported lower levels of neuron production by aged animals in the subgranular and subventricular zones, the report of equivalent levels in the striatum indicates that the potential for self-repair following stroke persists in the aged brain. While the use of the organism's own stem cells has many advantages, this technique is in its infancy, and the field still awaits an unambiguous proof of principle.

Another experimental approach that has received considerably more attention is the use of external sources of stem cells. One important question is the type of cells that should be used. Both fetal [75] and murine stem cell lines $[76,77]$ have been used successfully as grafts to improve functional deficits after experimental stroke in rats. Adult stem cells, such as those derived from human umbilical cord blood, have also proven efficacious [7881].

The appropriate route of stem cell administration must also be determined. One approach is transplantation either into the lesioned hemisphere, the contralateral hemisphere or both. Other possible targets for stem cell administration are the striatum $[55,77]$, the cortical parenchyma or the cerebral ventricles [76]. Following unilateral stroke, the grafted stem cells appear to be attracted both to the site of damage and to the corresponding contralateral region, suggesting the existence of both local repair processes and those involved in plastic changes in contralateral motor pathways [76].

An additional second route of administration of stem cells is via the circulation, either intravenously [78, 8284] or by injection into the carotid artery [85]. The field of stroke therapy using stem cells is a new but promising area, and it is hoped that studies to be carried out in the near future may validate a general therapeutic approach.

\section{Conclusions}

These results show that: (1) compared to young rats, aged rats develop a larger infarct area, as well as a necrotic zone characterized by a higher rate of cellular degeneration, and a larger number of apoptotic cells; (2) in both aged and young rats, the early, intense, proliferative activity following stroke leads to a precipitous formation of growth-inhibiting scar tissue, a phenomenon amplified by the persistent expression of neurotoxic factors, and (3) the regenerative potential of the rat brain is largely preserved up to 20 months of age but gene expression, temporally displaced, has a lower amplitude and is sometimes of relatively short duration.

\section{References}

1 Grady CL, Craik FI: Changes in memory processing with age. Curr Opin Neurobiol 2000;10:224-231.

2 Clayton DA, Mesches MH, Alvarez E, Bickford PC, Browning MD: A hippocampal NR2B deficit can mimic age-related changes in long-term potentiation and spatial learning in the Fischer 344 rat. J Neurosci 2002; 22:3628-3637.
Mesches MH, Gemma C, Veng LM, Allgeier C, Young DA, Browning MD, Bickford PC: Sulindac improves memory and increases NMDA receptor subunits in aged Fischer 344 rats. Neurobiol Aging 2004;25:315-324.

-4 Navarro A, Gomez C, Sanchez-Pino MJ, Gonzalez H, Bandez MJ, Boveris AD, Boveris A: Vitamin $\mathrm{E}$ at high doses improves survival, neurological performance, and brain mitochondrial function in aging male mice. Am J Physiol 2005;289:R1392-R1399.
5 Ay H, Koroshetz WJ, Vangel M, Benner T, Melinosky C, Zhu M, Menezes N, Lopez CJ, Sorensen AG: Conversion of ischemic brain tissue into infarction increases with age. Stroke 2005;36:2632-2636.

6 Barnett HJ: Stroke prevention in the elderly. Clin Exp Hypertens 2002;24:563-571.

7 Broderick JP: William M. Feinberg Lecture: stroke therapy in the year 2025: burden, breakthroughs, and barriers to progress. Stroke 2004;35:205-211. 
8 American Heart Association: Heart disease and stroke statistics update 2006.

$\longrightarrow 9$ Seshadri S, Beiser A, Kelly-Hayes M, Kase CS, Au R, Kannel WB, Wolf PA: The lifetime risk of stroke: estimates from the Framingham Study. Stroke 2006;37:345-350.

10 Wang LC, Futrell N, Wang DZ, Chen FJ, Zhai QH, Schulz LR: A reproducible model of middle cerebral infarcts, compatible with long-term survival, in aged rats. Stroke 1995; 26:2087-2090.

-11 Popa-Wagner A, Schroder E, Walker LC, Kessler C: Beta-amyloid precursor protein and ssamyloid peptide immunoreactivity in the rat brain after middle cerebral artery occlusion: effect of age. Stroke 1998;29:2196-2202.

-12 Brown AW, Marlowe KJ, Bjelke B: Age effect on motor recovery in a post-acute animal stroke model. Neurobiol Aging 2003;24: 607-614.

13 Markus TM, Tsai SY, Bollnow MR, Farrer RG, O'Brien TE, Kindler-Baumann DR, Rausch M, Rudin M, Wiessner C, Mir AK, Schwab ME, Kartje GL: Recovery and brain reorganization after stroke in adult and aged rats. Ann Neurol 2005;58:950-953.

- 14 Subramanyam B, Pond SM, Eyles DW, Whiteford HA, Fouda Stroke Therapy Academic Industry Roundtable (STAIR): Recommendations for standards regarding preclinical neuroprotective and restorative drug development. Stroke 1999;30:2752-2758.

-15 Lindner MD, Gribkoff VK, Donlan NA, Jones TA: Long-lasting functional disabilities in middle-aged rats with small cerebral infarcts. J Neurosci 2003;23:10913-10922.

16 Buchhold B, Mogoanta L, Suofu Y, Hamm A, Walker L, Kessler C, Popa-Wagner A: Environmental enrichment improves functional and neuropathological indices following stroke in young and aged rats. Restorative Neurol Neurosci 2007, in press.

17 Sutherland GR, Dix GA, Auer RN: Effect of age in rodent models of focal and forebrain ischemia. Stroke 1996;27:1663-1667.

$\checkmark 18$ Rosen CL, Dinapoli VA, Nagamine T, Crocco T: Influence of age on stroke outcome following transient focal ischemia. J Neurosurg 2005; 103:687-694.

19 Macri MA, D’Alessandro N, Di Giulio C, Di Iorio P, Di Luzio S, Giuliani P, Bianchi G, Esposito E: Regional changes in the metabolite profile after long-term hypoxia-ischemia in brains of young and aged rats: a quantitative proton MRS study. Neurobiol Aging 2006; 27:98-104.

20 Zhang L, Zhang RL, Wang Y, Zhang C, 32 Zhang ZG, Meng H, Chopp M: Functional recovery in aged and young rats after embolic stroke: treatment with aphosphodiesterase type 5 inhibitor. Stroke 2005;36:847-852.

- 21 Engelter ST, Provenzale JM, Petrella JR, De Long DM, Alberts MJ: Infarct volume on apparent diffusion coefficient maps correlates with length of stay and outcome after middle cerebral artery stroke. Cerebrovasc Dis 2003; $15: 188-191$
22 Nakayama H, Jorgensen HS, Raaschou HO, Olsen TS: The influence of age on stroke outcome. The Copenhagen Stroke Study. Stroke 1994;25:808-813.

23 Zhao CS, Puurunen K, Schallert T, Sivenius J, Jolkkonen J: Effect of cholinergic medication, before and after focal photothrombotic ischemic cortical injury, on histological and functional outcome in aged and young adult rats. Behav Brain Res 2005;156:85-94.

24 Badan I, Buchhold B, Hamm A, Gratz M, Walker LC, Platt D, Kessler C, Popa-Wagner A: Accelerated glial reactivity to stroke in aged rats correlates with reduced functional recovery. J Cereb Blood Flow Metab 2003;23: 845-854.

25 Zhao CS, Puurunen K, Schallert T, Sivenius J, Jolkkonen J: Behavioral and histological effects of chronic antipsychotic and antidepressant drug treatment in aged rats with focal ischemic brain injury. Behav Brain Res 2005;158:211-220.

26 Badan I, Dinca I, Buchhold B, Suofu Y, Walker L, Gratz M, Platt D, Kessler Ch, PopaWagner A: Accelerated accumulation of Nand C-terminal betaAPP fragments and delayed recovery of microtubule-associated protein $1 \mathrm{~B}$ expression following stroke in aged rats. Eur J Neurosci 2004;19:2270 2280.

-27 Popa-Wagner A, Badan I, Walker L, Groppa S, Patrana N, Kessler CH: Accelerated infarct development, cytogenesis and apoptosis following transient cerebral ischemia in aged rats. Acta Neuropathol (Berlin) 2007;113: 277-293.

28 Lee JC, Cho GS, Choi BO, Kim HC, Kim YS, Kim WK: Intracerebral hemorrhage-induced brain injury is aggravated in senescence-accelerated prone mice. Stroke 2006; 37:216-222

29 Popa-Wagner A, Schröder E, Schmoll H, Walker LC, Kessler C: Upregulation of MAP1B and MAP2 in the rat brain following middle cerebral artery occlusion: effect of age. J Cereb Blood Flow Metab 1999;19:425434.

30 LiS, Carmichael ST: Growth-associated gene and protein expression in the region of axonal sprouting in the aged brain after stroke. Neurobiol Dis 2006;23:362-373.

31 Carmichael ST, Archibeque I, Luke L, Nolan T, Momiy J, Li S: Growth-associated gene expression after stroke: evidence for a growthpromoting region in periinfarct cortex. Exp Neurol 2005;193:291-311.

2 Brenner D, Labreuche J, Touboul PJ, SchmidtPetersen K, Poirier O, Perret C, Schonfelder J, Combadiere C, Lathrop M, Cambien F, Brand-Herrmann SM, Amarenco P: Cytokine polymorphisms associated with carotid intima-media thickness in stroke patients. GENIC investigators. Stroke 2006;37:16911696.
33 Tang Y, Xu H, Du X, Lit L, Walker W, Lu A, Ran R, Gregg JP, Reilly M, Pancioli A, Khoury JC, Sauerbeck LR, Carrozzella JA, Spilker J, Clark J, Wagner KR, Jauch EC, Chang DJ, Verro P, Broderick JP, Sharp FR: Gene expression in blood changes rapidly in neutrophils and monocytes after ischemic stroke in humans: a microarray study. J Cereb Blood Flow Metab 2006;26:10891102.

34 Lucas SM, Rothwell NJ, Gibson RM: The role of inflammation in CNS injury and disease. Br J Pharmacol 2006; 147(suppl 1):S232S240.

- 35 Alarcon F, Zijlmans JC, Duenas G, Cevallos $\mathrm{N}$ : Post-stroke movement disorders: report of 56 patients. J Neurol Neurosurg Psychiatry 2004;75:1568-1574.

36 Price CJ, Crinion J: The latest on functional imaging studies of aphasic stroke. Curr Opin Neurol 2005;18:429-434.

- 37 Ward NS, Cohen LG: Mechanisms underlying recovery of motor function after stroke. Arch Neurol 2004;61:1844-1848.

-38 Gozal D, Row BW, Kheirandish L, Li R, Guo RL, Qiang F, Brittian KR: Increased susceptibility to intermittent hypoxia in aging rats: changes in proteasomal activity, neuronal apoptosis and spatial function. J Neurochem 2003;86:1545-1552.

-39 Hiona A, Leeuwenburgh C: Effects of age and caloric restriction on brain neuronal cell death/survival. Ann NY Acad Sci 2004;1019: 96-105.

-40 Martinez-Lara E, Canuelo AR, Siles E, Hernandez R, Del Moral ML, Blanco S, Pedrosa JA, Rodrigo J, Peinado MA: Constitutive nitric oxide synthases are responsible for the nitric oxide production in the ischemic aged cerebral cortex. Brain Res 2005;1054:88-94.

41 Riddle DR, Sonntag WE, Lichtenwalner RJ: Microvascular plasticity in aging. Ageing Res Rev 2003;2:149-168.

$\checkmark 42$ Hajdu MA, Heistad DD, Siems JE, Baumbach GL: Effects of aging on mechanics and composition of cerebral arterioles in rats. Circ Res 1990;66:1747-1754.

43 Stoll G, Jander S, Schroeter M: Inflammation and glial responses in ischemic brain lesions. Progress in Neurobiology 1998;56:149-171.

-44 Justicia C, Martin A, Rojas S, Gironella M, Cervera A, Panes J, Chamorro A, Planas AM: Anti-VCAM-1 antibodies did not protect against ischemic damage either in rats or in mice. J Cereb Blood Flow Metab 2005;26: 421-432.

45 del Zoppo GJ, Becker KJ, Hallenbeck JM: Inflammation after stroke: is it harmful? Arch Neurol 2001;58:669-672.

46 Iadecola C, Alexander M: Cerebral ischemia and inflammation. Curr Opin Neurol 2001; 14:89-94.

47 Roberts EL Jr, Chih CP, Rosenthal M: Agerelated changes in brain metabolism and vulnerability to anoxia. Adv Exp Med Biol 1997;411:83-89. 
-48 Floyd RA, Hensley K: Nitrone inhibition of age-associated oxidative damage. Ann NY Acad Sci 2000;899:222-237.

-49 Hoane MR, Lasley LA, Akstulewicz SL: Middle age increases tissue vulnerability and impairs sensorimotor and cognitive recovery following traumatic brain injury in the rat. Behav Brain Res 2004;153:189-197.

-50 Aliev G, Smith MA, Seyidov D, Neal ML, Lamb BT, Nunomura A, Gasimov EK, Vinters HV, Perry G, LaManna JC, Friedland RP: The role of oxidative stress in the pathophysiology of cerebrovascular lesions in Alzheimer's disease. Brain Pathol 2002; 12:21-35.

- 51 Oster-Granite ML, McPhie DL, Greenan J, Neve RL: Age-dependent neuronal and synaptic degeneration in mice transgenic for the $\mathrm{C}$ terminus of the amyloid precursor protein. J Neurosci 1996;16:6732-6741.

- 52 Nalbantoglu J, Santiago-Tirado G, Lahsaini A, Poirier J, et al: Impaired learning and LTP in mice expressing the carboxy terminus of the Alzheimer amyloid precursor protein. Nature 1997;387:500-505.

-53 Nishimura I, Uetsuki T, Dani SU, Ohsawa Y, Saito I, Okamura H, Uchiyama Y, Yoshikawa $\mathrm{K}$ : Degeneration in vivo of rat hippocampal neurons by wild-type Alzheimer amyloid precursor protein overexpressed by adenovirus-mediated gene transfer. J Neurosci 1998; 18:2387-2398.

54 Jin K, Minami M, Xie L, Sun Y, Mao XO, Wang Y, Simon RP, Greenberg DA: Ischemia-induced neurogenesis is preserved but reduced in the aged rodent brain. Aging Cell 2004;3:373-377.

-55 Darsalia V, Heldmann U, Lindvall O, Kokaia Z: Stroke-induced neurogenesis in aged brain. Stroke 2005;36:1790-1795.

-56 Priller J, Persons DA, Klett FF, Kempermann G, Kreutzberg GW, Dirnagl U: Neogenesis of cerebellar Purkinje neurons from genemarked bone marrow cells in vivo. J Cell Biol 2001;155:733-738.

57 Vallieres L, Sawchenko PE: Bone marrowderived cells that populate the adult mouse brain preserve their hematopoietic identity. J Neurosci 2003;23:5197-5207.

- 58 Hess DC, Hill WD, Carroll JE, Borlongan CV: Do bone marrow cells generate neurons? Arch Neurol 2004;61:483-485.

-59 Suzuki Y, Takagi Y, Nakamura R, Hashimoto K, Umemura K: Ability of NMDA and non-NMDA receptor antagonists to inhibit cerebral ischemic damage in aged rats. Brain Res 2003;964:116-120.

-60 He Z, Crook JE, Meschia JF, Brott TG, Dickson DW, McKinney M: Aging blunts ischemic-preconditioning-induced neuroprotection following transient global ischemia in rats. Curr Neurovasc Res 2005;2:365374 .
61 Wise PM: Estrogen therapy: Does it help or hurt the adult and aging brain? Insights derived from animal models. Neuroscience 2006;138:831-835.

62 Dubal DB, Rau SW, Shughrue PJ, Zhu H, Yu J, Cashion AB, Suzuki S, Gerhold LM, Bottner MB, Dubal SB, Merchanthaler I, Kindy MS, Wise PM: Differential modulation of estrogen receptors (ERs) in ischemic brain injury: a role for ER alpha in estradiolmediated protection against delayed cell death. Endocrinology 2006;147:3076-3084.

63 Haas S, Weidner N, Winkler J: Adult stem cell therapy in stroke. Curr Opin Neurol 2005; 18:59-64.

64 Bliss T, Guzman R, Daadi M, Steinberg GK: Cell transplantation therapy for stroke. Stroke 2007;38:817-826.

65 Mirich JM, Williams NC, Berlau DJ, Brunjes PC: Comparative study of aging in the mouse olfactory bulb. J Comp Neurol 2002;454: 361-372.

66 Jin K, Minami M, Xie L, Sun Y, Mao XO, Wang Y, Simon RP, Greenberg DA: Ischemia-induced neurogenesis is preserved but reduced in the aged rodent brain. Aging Cell 2004;3:373-377.

67 Kempermann G, Gast D, Gage FH: Neuroplasticity in old age: sustained fivefold induction of hippocampal neurogenesis by long-term environmental enrichment. Ann Neurol 2002;52:135-143.

68 Tropepe V, Craig CG, Morshead CM, van der Kooy D: Transforming growth factor-alpha null and senescent mice show decreased neural progenitor cell proliferation in the forebrain subependyma. J Neurosci 1997;17: $7850-7859$.

69 Bondolfi L, Ermini F, Long JM, Ingram DK, Jucker M: Impact of age and caloric restriction on neurogenesis in the dentate gyrus of C57BL/6 mice. Neurobiol Aging 2004;25: 333-340.

70 Heine VM, Maslam S, Joels M, Lucassen PJ: Prominent decline of newborn cell proliferation, differentiation, and apoptosis in the aging dentate gyrus, in absence of an age-related hypothalamus-pituitary-adrenal axis activation. Neurobiol Aging 2004;25:361375.

71 Cameron HA, McKay RD: Restoring production of hippocampal neurons in old age. Nat Neurosci 1999;2:894-897.

72 Kempermann G, Kuhn HG, Gage FH: Experience-induced neurogenesis in the senescent dentate gyrus. J Neurosci 1998; 18:32063212.

73 Decker L, Picard-Riera N, Lachapelle F, Baron-Van Evercooren A: Growth factor treatment promotes mobilization of young but not aged adult subventricular zone precursors in response to demyelination. J Neurosci Res 2002;69:763-771.
4 Gray WP, May K, Sundström LE: Seizure induced dentate neurogenesis does not diminish with age in rats. Neurosci Lett 2002;330: 235-238.

75 Sorensen JC, Grabowski M, Zimmer J, Johansson BB: Fetal neocortical tissue blocks implanted in brain infarcts of adult rats interconnect with the host brain. Exp Neurol 1996;138:227-235.

76 Modo M, Stroemer RP, Tang E, Patel S, Hodges H: Effects of implantation site of stem cell grafts on behavioral recovery from stroke damage. Stroke 2002;33:2270-2278.

77 Wong AM, Hodges H, Horsburgh K: Neural stem cell grafts reduce the extent of neuronal damage in a mouse model of global ischaemia. Brain Res 2005;1063:140-150.

-78 Lu D, Sanberg PR, Mahmood A, Li Y, Wang L, Sanchez-Ramos J, Chopp M: Intravenous administration of human umbilical cord blood reduces neurological deficit in the rat after traumatic brain injury. Cell Transplant 2002;11:275-281.

79 Saporta S, Kim JJ, Willing AE, Fu ES, Davis CD, Sanberg PR: Human umbilical cord blood stem cells infusion in spinal cord injury: engraftment and beneficial influence on behavior. Hematother Stem Cell Res 2003; 12:271-278.

80 Xiao J, Nan Z, Motooka Y, Low WC: Transplantation of a novel cell line population of umbilical cord blood stem cells ameliorates neurological deficits associated with ischemic brain injury. Stem Cells Dev 2005;14: 722-733.

-81 Nan Z, Grande A, Sanberg CD, Sanberg PR, Low WC: Infusion of human umbilical cord blood ameliorates neurologic deficits in rats with hemorrhagic brain injury. Ann NY Acad Sci 2005; 1049:84-96.

82 Willing AE, Vendrame M, Mallery J, Cassady CJ, Davis CD, Sanchez-Ramos J, Sanberg PR: Mobilized peripheral blood cells administered intravenously produce functional recovery in stroke. Cell Transplant 2003;12:449-454.

83 Liu H, Honmou O, Harada K, Nakamura K, Houkin K, Hamada H, Kocsis JD: Neuroprotection by PlGF gene-modified human mesenchymal stem cells after cerebral ischaemia. Brain 2006;129:2734-2745.

-84 Honma T, Honmou O, Iihoshi S, Harada K, Houkin K, Hamada H, Kocsis JD: Intravenous infusion of immortalized human mesenchymal stem cells protects against injury in a cerebral ischemia model in adult rat. Exp Neurol 2006;199:56-66.

85 Shen LH, Li Y, Chen J, Zhang J, Vanguri P, Borneman J, Chopp M: Intracarotid transplantation of bone marrow stromal cells increases axon-myelin remodeling after stroke. Neuroscience 2006;137:393-399. 